\title{
Parameters Associated with Adverse Fetal Outcomes in Parvovirus B19 Congenital Infection
}

\section{Parâmetros associados a desfechos fetais adversos na infecção congênita pelo parvovírus B19}

\author{
Isabela Karine Rodrigues Agra ${ }^{1}$ Antonio Gomes Amorim Filho ${ }^{1}$ Lawrence Hsu Lin ${ }^{1}$ \\ Sckarlet Ernandes Biancolin ${ }^{1}$ Rossana Pulcineli Vieira Francisco ${ }^{1}$ Maria de Lourdes Brizot ${ }^{1}$ \\ ${ }^{1}$ Hospital das Clínicas - Department of Gynecology and Obstetrics, \\ Obstetrics Discipline, Universidade de São Paulo, São Paulo, \\ São Paulo, Brazil \\ Address for correspondence Maria de Lourdes Brizot, Professor, \\ Universidade de São Paulo, Av. Dr Enéas de Carvalho Aguiar 255, \\ $10^{\circ}$ andar, sala 10.037, 05403-000, São Paulo, SP, Brazil \\ (e-mail: mlbrizot@uol.com.br).
}

Rev Bras Ginecol Obstet 2017;39:596-601. received

March 25, 2017

accepted

August 30, 2017

published online

September 25, 2017
Objective To investigate the clinical and sonographic parameters associated with adverse fetal outcomes in patients with congenital parvovirus B19 infection managed by intrauterine transfusion.

Methods This was a single-center retrospective study conducted from January 2005 to December 2016 that assessed patients with singleton pregnancies with fetal parvovirus infection confirmed by a polymerase chain reaction of the amniotic fluid or fetal blood samples who underwent at least one intrauterine transfusion. The maternal characteristics, sonographic findings and parameters related to intrauterine transfusion were compared between the two groups (recovery/non-recovery), who were categorized based on fetal response after in-utero transfusions. Progression to fetal death or delivery without fetal recovery after the transfusions was considered nonrecovery and categorized as an adverse outcome.

Results The final analysis included ten singleton pregnancies: seven of which were categorized into the recovery group and three of which into the non-recovery group. The baseline characteristics were similar between the groups. All fetuses were hydropic at the time of diagnosis. No significant differences related to sonographic or intrauterine transfusion parameters were identified between the groups; however, the nonrecovery group tended to have an increased number of sonographic markers and lower fetal hemoglobin and platelet levels before the transfusion.

Conclusion We were unable to firmly establish the clinical or sonographic parameters associated with adverse fetal outcomes in patients with parvovirus infection managed with intrauterine transfusions; however, edema, placental thickening and oligohydramnios may indicate greater fetal compromise and, subsequently, adverse outcomes. However, further studies are necessary, mainly due to the small number of cases analyzed in the present study.

intrauterine transfusion

Copyright @ 2017 by Thieme Revinter

Publicações Ltda, Rio de Janeiro, Brazil
License terms

(c) $(1) \$$
$10.1055 / \mathrm{s}-0037-1606859$.

ISSN $0100-7203$ 


\section{Resumo}

\section{Palavras-chave}

- parvovírus B19

- prognóstico

- ultrassonografia

- resultado da gravidez

- transfusão de sangue intrauterina
Objetivo Investigar os parâmetros clínicos e ultrassonográficos associados ao desfecho fetal adverso em pacientes com infecção congênita por parvovírus B19 manejada por meio de transfusão intrauterina.

Métodos Trata-se de um estudo retrospectivo de um único centro realizado entre janeiro de 2005 e dezembro de 2016, que avaliou pacientes com gestação única com infecção fetal por parvovírus confirmada por reação em cadeia da polimerase de líquido amniótico ou amostras de sangue fetal submetidas a pelo menos uma transfusão intrauterina. As características maternas, os achados ultrassonográficos e os parâmetros relacionados à transfusão intrauterina foram comparados entre os dois grupos (recuperação/não recuperação), que foram categorizados com base na resposta fetal após transfusão intrauterina. A progressão para morte fetal ou parto sem recuperação fetal após transfusões foi considerada não recuperação, e categorizada como um desfecho adverso.

Resultados A análise final incluiu dez gravidezes únicas: sete foram categorizadas no grupo de recuperação, e três, no grupo de não recuperação. As características basais foram semelhantes entre os grupos. Todos os fetos estavam hidrópicos no momento do diagnóstico. Não foram identificadas diferenças significativas entre os grupos em relação aos parâmetros ultrassonográficos ou os das transfusões intrauterinas; Entretanto, o grupo de não recuperação tendeu a ter um número aumentado de marcadores ultrassonográficos e níveis mais baixos de hemoglobina e plaquetas fetais antes da transfusão.

Conclusão Não foi possível estabelecer firmemente os parâmetros clínicos ou ultrassonográficos associados ao desfecho fetal adverso em pacientes com infecção por parvovírus manejada por meio de transfusões intrauterinas. Entretanto, edema de pele, espessamento placentário e oligoidrâmnio podem indicar maior comprometimento fetal e, posteriormente, desfechos fetais adversos. No entanto, estudos adicionais são necessários, principalmente devido ao pequeno número de casos analisados neste estudo.

\section{Introduction}

Parvovirus B19 is a small DNA virus that was first described in 1974 and infects only humans. The viral structure is simple, consisting of only two structural proteins and a single-stranded DNA molecule, making this virus extremely resistant to physical inactivation. ${ }^{1}$ This virus usually causes self-limited disease and symptoms, including fever and an erythematous rash that resolves within 7 to 10 days. ${ }^{2}$ Due to its cytotoxic activity and tropism to erythroid progenitor cells, megakaryocytes and myocytes, concerns about the effects of fetal transmission have been voiced. ${ }^{3}$

Fetal infections are essentially diagnosed by a polymerase chain reaction (PCR) of the amniotic fluid or fetal blood samples. In addition, ultrasonography can be used to provide evidence of fetal insults caused by the affinity of the virus to erythroid stem cells and myocytes, causing fetal anemia and cardiomyopathy, and eventually leading to hydrops fetalis. ${ }^{4,5}$ Although some cases of fetal infection have been spontaneously resolved cases under suspicion or with a confirmed diagnosis, they demand increased surveillance by Doppler assessment of the middle cerebral artery (MCA) and an accurate evaluation of cavity effusion. ${ }^{6}$ The risk of hydrops has been found to decrease significantly if the infection occurs during the late second or third trimesters, mainly due to the maturation of the fetal immunologic system. ${ }^{7,8}$

If there is evidence of fetal hydrops or anemia, indicated via increased peak systolic velocity (PSV) of the MCA, a cordocentesis should be performed, and an intrauterine transfusion (IUT) may be indicated when technically feasible. ${ }^{9}$ In the presence of hydrops, the mortality rate can reach almost $50 \%$, and evidence suggests that this rate decreases to $\sim 18 \%$ in cases treated with IUTs. ${ }^{9,10}$ Compared with cases of immune hydrops fetalis, fetal recovery following IUT can be slower in B19-infected fetuses, mainly due to bone marrow suppression. ${ }^{11}$

In our literature search, we did not find studies examining variables other than hydrops in association with fetal response in patients with congenital parvovirus B19 infection who had undergone IUT. In addition, the series presented in the literature included low numbers of cases. Therefore, we present our series of cases and investigate the clinical and sonographic parameters associated with the prognosis. 


\section{Methods}

This was a retrospective study that was conducted from January 2005 to December 2016 in the Fetal Medicine Unit of the Department of Obstetrics and Gynecology of a Medical School in the city of São Paulo, Brazil. All women with singleton pregnancies and confirmed fetal infection by parvovirus B19 who underwent IUTs were included. The study was approved by the local Ethics in Research Committee (under protocol number 65113417.1.0000.0068).

A database search was performed to identify all women with singleton pregnancies and parvovirus B19 infection who fulfilled the following inclusion criteria: isolated parvovirus fetal infection that had been confirmed via PCR of the amniotic fluid or fetal blood samples and managed with at least one IUT and with a known pregnancy outcome. Pregnancy outcome data were retrieved from the hospital records.

Pregnant women with a diagnosis of fetal hydrops were referred to our tertiary center for specialist care. A detailed fetal anomaly scan was performed by experienced sonographers to confirm the abnormality. Voluson 730 Expert, a Voluson E8 (General Electric Healthcare, Vienna, Austria) and an Envisor (Phillips, Andover, MA, US) ultrasound machines that were equipped with $3.5-5.0 \mathrm{MHz}$ curvilinear abdominal transducers were used. The sonographic parameters evaluated included the following: fetal growth, placental thickness and echogenicity, amniotic fluid volume, presence of hydrops (defined as abnormal fluid accumulation in the serous cavities or in the interstitium of the fetal tissues, such as skin edema, pleural effusion, pericardial effusion or ascites - at least two of which were required), ${ }^{12}$ cardiomegaly and Doppler assessment of fetal anemia via the PSV of the MCA (values greater than 1.5 multiples of median [MoMs] were considered risk of fetal anemia). ${ }^{13}$

For the data analysis, the pregnancies were divided into two groups (recovery/non-recovery) based on response to fetal transfusions as follows: progression to fetal death or lack of sonographic improvement before delivery was considered non-recovery and classified as an adverse prognosis.

Each sonographic parameter was analyzed separately and then combined to count the total number of ultrasound parameters for each group. In order to do this, 1 point was attributed to any positive parameter: placental thickening (defined as placental thickness $>40 \mathrm{~mm}$ ); oligohydramnios; ascites; pericardial effusion; pleural effusion, subcutaneous edema and cardiomegaly. The number of abnormal markers was compared between both groups.

All transfusions were performed using fresh type O Rh (D) negative adult packed red blood cells that had had been previously irradiated with $25 \mathrm{~Gy}$ of gamma radiation, washed, and filtered. The amount of blood transfused during each procedure was calculated to achieve a post-transfusion fetal hemoglobin $(\mathrm{Hb})$ level equivalent to at least the 95 th percentile for the corresponding gestational age (GA), or a total fetoplacental volume expansion of $50 \%{ }^{14}$ We analyzed the characteristics related to the IUT, including gestational age at first IUT, number of IUTs, fetal blood parameters at first IUT (hemoglobin and platelet levels), and interval in days between the first
IUT and fetal response (ranging from fetal recovery and intrauterine death [IUD] to delivery without fetal recovery). The birth weight was classified according to a Brazilian population range and compared between the groups. ${ }^{15}$

The data were analyzed using the Statistical Package for the Social Sciences (IBM SPSS Statistics for Windows, IBM Corp., Armonk, NY, US) software, version 20.0. The continuous data were expressed as the median. In order to perform the comparisons between the groups, the Mann-Whitney U-test was used for the quantitative variables, and the Fisher exact test was used for the qualitative variables. A value of $p<0.05$ was considered statistically significant.

\section{Results}

The initial database search returned 13 patients who fulfilled our inclusion criteria. However, three of them did not return for a sonographic evaluation after the IUT, and did not have pregnancy outcome data. Therefore, the final data analysis included ten cases: seven in the recovery group and three in the non-recovery group.

The maternal characteristics at the time of the diagnosis of fetal infection were similar in both groups (-Table 1). Concerning the pregnancy characteristics, the members of the non-recovery group were referred to our services at a later GA; however, this difference was not significant. This group also delivered earlier, resulting in smaller neonates, mainly due to the adverse outcomes related to these pregnancies.

The isolated evaluation of each sonographic parameter demonstrated the presence of no difference between the

Table 1 Baseline characteristics of the study population according to fetal outcome

\begin{tabular}{|c|c|c|c|}
\hline Variables & $\begin{array}{l}\text { Recovery } \\
\text { group } \\
(n=7)\end{array}$ & $\begin{array}{l}\text { Non-recovery } \\
\text { group }(n=3)\end{array}$ & $p$ \\
\hline \multicolumn{4}{|l|}{ Maternal } \\
\hline Age, years & $25(17-31)$ & $27(16-32)$ & $0.99^{a}$ \\
\hline White color, n (\%) & $5(71.4)$ & $2(66.7)$ & $0.99^{b}$ \\
\hline $\begin{array}{l}\text { Educational level, } \\
\text { years }\end{array}$ & $10(8-14)$ & $6(6-14)$ & $0.38^{a}$ \\
\hline Nulliparous, n (\%) & $4(80)$ & $2(66.7)$ & $0.99^{b}$ \\
\hline \multicolumn{4}{|l|}{ Pregnancy and perinatal } \\
\hline $\begin{array}{l}\text { Gestational age at } \\
\text { ultrasound diagnosis }\end{array}$ & $\begin{array}{l}22.7 \\
(21-27.5)\end{array}$ & $\begin{array}{l}24.4 \\
(24.2-26.5)\end{array}$ & $0.11^{a}$ \\
\hline $\begin{array}{l}\text { Gestational age at } \\
\text { delivery }\end{array}$ & $\begin{array}{l}37.0 \\
(28.7-40.4)\end{array}$ & $\begin{array}{l}27.0 \\
(24.8-29.5)\end{array}$ & $0.03^{a}$ \\
\hline $\begin{array}{l}\text { Delivery by cesarean, } \\
\mathrm{n}(\%)\end{array}$ & $5(71.4)$ & $1(33.3)$ & $0.50^{\mathrm{b}}$ \\
\hline Birth weight, grams & $\begin{array}{l}2,500 \\
(900-3,200)\end{array}$ & $\begin{array}{l}1,000 \\
(800-1,500)\end{array}$ & $0.06^{\mathrm{a}}$ \\
\hline $\begin{array}{l}\text { Apgar score }<7 \text { at } \\
5 \text { minutes, } n / N(\%)\end{array}$ & $0 / 7(0)$ & $1 / 2(50)$ & $0.28^{\mathrm{b}}$ \\
\hline $\begin{array}{l}\text { Birth weight }<10 \text { th } \\
\text { percentile, } n / N(\%)\end{array}$ & $4 / 7(57.1)$ & $0 / 2$ & $0.44^{\mathrm{b}}$ \\
\hline Perinatal death, n (\%) & $0(0)$ & $3(100)$ & $0.008^{b}$ \\
\hline
\end{tabular}

Notes: Data described as the median (range); ${ }^{a}$ Mann-Whitney test; ${ }^{b}$ Fisher exact test. 
Table 2 Sonographic parameters at the time of the diagnosis according to fetal outcome

\begin{tabular}{|l|l|l|l|}
\hline Variables & $\begin{array}{l}\text { Recovery } \\
\text { group } \\
(\boldsymbol{n}=7)\end{array}$ & $\begin{array}{l}\text { Non-recovery } \\
\text { group }(\boldsymbol{n}=3)\end{array}$ & $p$ \\
\hline $\begin{array}{l}\text { Placental thickness, } \\
\text { mm, n/N }\end{array}$ & $\begin{array}{l}42.50 \\
(34-64), \\
6 / 7\end{array}$ & $\begin{array}{l}83.50 \\
(83-84), \\
2 / 3\end{array}$ & $0.07^{\mathrm{a}}$ \\
\hline $\begin{array}{l}\text { Oligohydramnios, } \\
\mathrm{n}(\%)\end{array}$ & $1(14.3)$ & $1(33.3)$ & $0.99^{\mathrm{b}}$ \\
\hline Ascites, n (\%) & $7(100)$ & $3(100)$ & $0.99^{\mathrm{b}}$ \\
\hline $\begin{array}{l}\text { Pericardial } \\
\text { effusion, n (\%) }\end{array}$ & $7(100)$ & $3(100)$ & $0.99^{\mathrm{b}}$ \\
\hline $\begin{array}{l}\text { Pleural effusion, } \\
\mathrm{n}(\%)\end{array}$ & $1(14.3)$ & $0(0)$ & $0.99^{\mathrm{b}}$ \\
\hline $\begin{array}{l}\text { Subcutaneous } \\
\text { edema, n (\%) }\end{array}$ & $3(42.9)$ & $3(100)$ & $0.20^{\mathrm{b}}$ \\
\hline $\begin{array}{l}\text { Cardiomegaly, } \\
\mathrm{n}(\%)\end{array}$ & $7(100)$ & $3(100)$ & $0.99^{\mathrm{b}}$ \\
\hline $\begin{array}{l}\text { Hydrops } \\
\text { diagnosis, n (\%) }\end{array}$ & $7(100)$ & $3(100)$ & $0.99^{\mathrm{b}}$ \\
\hline $\begin{array}{l}\text { PSV of the MCA } \\
\text { (MoMs) }\end{array}$ & $\begin{array}{l}3.10 \\
(2.1-3.4)\end{array}$ & $\begin{array}{l}2.30 \\
(2.2-4.1)\end{array}$ \\
\hline $\begin{array}{l}\text { Number of } \\
\text { US markers }\end{array}$ & $4(3-6)$ & $5(5-6)$ & $0.33^{\mathrm{a}}$ \\
\hline
\end{tabular}

Abbreviation: MCA, middle cerebral artery; MoMs, multiples of the median; PSV, peak systolic velocity; US, ultrasound.

Notes: Data described as the median (range); ${ }^{a}$ Mann-Whitney test; ${ }^{\mathrm{b}}$ Fisher exact test.

groups; while in the non-recovery group we observed thicker placentas and higher prevalence of subcutaneous edema, no significant differences were identified ( - Table $\mathbf{2}$ ). All fetuses were hydropic at the time of the diagnosis, and ascites and pericardial effusion presented in all cases regardless of the group. When these sonographic parameters were analyzed together, the non-recovery group members had a slightly but not significantly increased number of markers.

In addition, no differences in IUT characteristics and in the interval to fetal response were identified between the groups (-Table 3). The peak systolic velocity of the MCA before the first IUT was similar in both groups. Despite the discrete tendency for non-recovery patients to present lower levels of fetal hemoglobin and platelets, no significant difference was observed.

All 7 cases included in the recovery group remained alive, and nearly half of them had birth weights below the 10th percentile $(57.1 \%, 4 / 7)$. The Doppler parameters of the umbilical artery were normal in these cases. Nevertheless, all three pregnancies belonging to the non-recovery group ended in perinatal death. In 1 case, an IUD occurred at 24.8 weeks of gestation, 4 days after an IUT that increased the fetal hemoglobin from $2.1 \mathrm{~g} / \mathrm{dl}$ to $10.1 \mathrm{~g} / \mathrm{dl}$, with no evidence of complications related to the intrauterine procedure; the other two perinatal losses occurred in the neonatal period, within 3 hours and 20 days after birth, before hospital discharge. In both cases,
Table 3 Intrauterine transfusion parameters and fetal outcomes

\begin{tabular}{|l|l|l|l|}
\hline Variables & $\begin{array}{l}\text { Recovery } \\
(\boldsymbol{n}=\mathbf{7})\end{array}$ & $\begin{array}{l}\text { Non-recovery } \\
(\boldsymbol{n}=3)\end{array}$ & $p^{\text {a }}$ \\
\hline Number of IUTs & $1(1-3)$ & $2(1-2)$ & 0.51 \\
\hline GA at first IUT & $\begin{array}{l}22.8 \\
(21.2-27.5)\end{array}$ & $\begin{array}{l}24.4 \\
(24.1-26.7)\end{array}$ & 0.11 \\
\hline $\begin{array}{l}\text { Fetal hemoglobin } \\
(\mathrm{g} / \mathrm{dl}) \text { at first IUT }\end{array}$ & $\begin{array}{l}4.0 \\
(2.3-6.7)\end{array}$ & $\begin{array}{l}2.75 \\
(2.1-3.4)\end{array}$ & 0.22 \\
\hline $\begin{array}{l}\text { Fetal platelets at } \\
\text { first IUT, } x 10^{3}, \mathrm{n} / \mathrm{N}\end{array}$ & $\begin{array}{l}85 \\
(40-92), 4 / 7\end{array}$ & $\begin{array}{l}35.5 \\
(22-49), 3 / 3\end{array}$ & 0.26 \\
\hline $\begin{array}{l}\text { Interval between } \\
\text { first IUT and fetal } \\
\text { response, days }\end{array}$ & $35(7-63)$ & $20(3-20)$ & 0.18 \\
\hline
\end{tabular}

Abbreviations: GA, gestational age; IUT, intrauterine transfusion. Notes: Data described as the median (range); ${ }^{a}$ Mann-Whitney test.

there was evidence of fetal distress at approximately 10 and 7 days after the last IUT ( $\mathrm{Hb}$ level after last IUT $=14 \mathrm{~g} / \mathrm{dl}$ and $12 \mathrm{~g} / \mathrm{dl}$ respectively), leading to cesarean delivery ( - Table 4 ).

\section{Discussion}

In the present study of women with singleton pregnancies and confirmed parvovirus B19 fetal infection, we did not identify any clinical or sonographic parameters associated with adverse fetal prognosis. In our opinion, this finding may be related to the small number of cases analyzed.

We identified no studies in the literature related to the association between sonographic markers other than hydrops and the clinical features to fetal outcomes in parvovirus congenital infection. Only two case series concerning the etiology and outcomes associated with fetal hydrops mentioned this viral infection, and no specific details about sonographic parameters related to fetal outcomes were provided in the studies. ${ }^{16,17}$ A larger series investigated 63 cases of fetal hydrops, 8 of which were related to parvovirus infection, and 5 of which were managed with IUTs. ${ }^{16}$ The majority of the cases had a favorable outcome $(87.5 \%, 7 / 8)$, and there was only 1 case of intrauterine death at 21 weeks of gestation.

In accordance with our findings, the authors reported that ascites were present in all affected fetuses, and they were associated with skin edema and pericardial effusion in the majority of the cases (seven out of eight). Pleural effusion was rare, occurring only in one fetus. ${ }^{16}$ Although fetal cardiomyopathy due to viral tropism to cardiac myocytes is well understood, ${ }^{4}$ cardiac dysfunction was not described in the aforementioned study, and was superficially evaluated in our analysis. An examination of fetal cardiac compromise was not completed via fetal echocardiography in our study, which could have contributed to a more objective assessment and to the provision of quantitative data on cardiac function, leading to a better interpretation of fetal prognosis.

Concerning the IUT parameters, fetal hemoglobin and platelet levels tend to be lower in fetuses with adverse outcomes, although no significant difference was found. In addition, all cases in the non-recovery group had significant and severe 
Table 4 Description of the clinical and sonographic characteristics of the reported cases

\begin{tabular}{|c|c|c|c|c|c|c|c|c|c|c|}
\hline Cases & $\begin{array}{l}\text { GA at } \\
\text { diagnosis } \\
\text { (weeks) }\end{array}$ & $\begin{array}{l}\text { Placental } \\
\text { thickening } \\
(\mathrm{mm})\end{array}$ & Oh. & Ascites & $\begin{array}{l}\text { Pericardial / } \\
\text { PE }\end{array}$ & SE & $\begin{array}{l}\text { Cardio- } \\
\text { megaly }\end{array}$ & $\begin{array}{l}\text { Total } \\
\text { IUT }\end{array}$ & $\begin{array}{l}\text { Hb/PLTs } \\
\text { before } \\
1^{\text {st }} \text { IUT }\end{array}$ & Fetal outcome \\
\hline 1 & 24.1 & Yes (83) & No & Yes & Yes/No & Yes & Yes & 2 & $2.1 / 26,000$ & $\begin{array}{l}\text { Non-recovery; } \\
\text { delivery at } 27 \text { weeks; } \\
\text { neonatal death. }\end{array}$ \\
\hline 2 & 26.5 & Yes (NA) & No & Yes & Yes/No & Yes & Yes & 2 & $3.4 / 22,000$ & $\begin{array}{l}\text { Non-recovery; } \\
\text { delivery at } 29 \text { weeks; } \\
\text { neonatal death. }\end{array}$ \\
\hline 3 & 24.2 & Yes (84) & Yes & Yes & Yes/No & Yes & Yes & 1 & $2.1 / 49,000$ & $\begin{array}{l}\text { Non-recovery; } \\
\text { IUD at } 24.8 \text { weeks. }\end{array}$ \\
\hline 4 & 22.0 & No (34) & No & Yes & Yes/No & No & Yes & 2 & $2.5 / 92,000$ & $\begin{array}{l}\text { Recovery; } \\
\text { delivery at } 37 \text { weeks; } \\
\text { alive. }\end{array}$ \\
\hline 5 & 21.0 & No (34) & No & Yes & Yes/No & No & Yes & 1 & 4.3/NA & $\begin{array}{l}\text { Recovery; } \\
\text { delivery at } 40 \text { weeks; } \\
\text { alive. }\end{array}$ \\
\hline 6 & 23.0 & Yes (45) & No & Yes & Yes/No & No & Yes & 1 & $5.6 / 85,000$ & $\begin{array}{l}\text { Recovery; } \\
\text { delivery at } 38 \text { weeks; } \\
\text { alive. }\end{array}$ \\
\hline 7 & 27.5 & Yes (NA) & No & Yes & Yes/No & No & Yes & 1 & $3.5 / 40,000$ & $\begin{array}{l}\text { Recovery; } \\
\text { delivery at } 28 \text { weeks; } \\
\text { alive. }\end{array}$ \\
\hline 8 & 23.7 & Yes (59) & No & Yes & Yes/No & Yes & Yes & 1 & 4.0/NA & $\begin{array}{l}\text { Recovery; } \\
\text { delivery at } 35 \text { weeks; } \\
\text { alive. }\end{array}$ \\
\hline 9 & 22.5 & Yes (45) & No & Yes & Yes/Yes & Yes & Yes & 3 & $2.3 / \mathrm{NA}$ & $\begin{array}{l}\text { Recovery; } \\
\text { delivery at } 33 \text { weeks; } \\
\text { alive. }\end{array}$ \\
\hline 10 & 22.7 & Yes (64) & Yes & Yes & Yes/No & Yes & Yes & 1 & $6.7 / 85,000$ & $\begin{array}{l}\text { Recovery; } \\
\text { delivery at } 38 \text { weeks; } \\
\text { alive. }\end{array}$ \\
\hline
\end{tabular}

Abbreviations: GA, gestational age; Hb, hemoglobin (g/dL); IUD, intrauterine death; IUT, intrauterine transfusion; NA, not available; Oh., oligohydramnios; PE, pleural effusion; PLTs, platelets; SE, subcutaneous edema.

anemia (below 4 standard deviations for GA), ${ }^{18}$ while in the recovery group this rate was lower, at nearly $70 \%$ (5/7 cases). Using data from a survey of members of the Society of Perinatal Obstetricians, a survival rate of $83.5 \%$ was found for hydropic fetuses that underwent IUT, ${ }^{19}$ whereas in our analysis, this percentage was of $\sim 70 \%$. Additionally, the interval between the first IUT and complete fetal recovery in that survey was of $\sim 6$ weeks, ${ }^{19}$ which is consistent with our data regarding fetal recovery (within 35 days; range: 7-63 days).

The lower survival rate after IUT observed in our study may be explained by the fact that the cases included in the non-recovery group were probably in more advanced stages of fetal compromise due to severe fetal anemia. All three cases included in this group exhibited subcutaneous edema associated with ascites and pericardial effusion by the time of the diagnosis; in addition, considerable placental thickening was observed. Furthermore, 33\% of those fetuses presented with oligohydramnios (1/3), but only $14 \%$ in the recovery group (1/7) presented with this condition. It is well-known that the inhibition of fetal hematopoiesis and hepatocytes by parvovirus infection first leads to ascites and pericardial effusion due to portal hypertension and hypoproteinemia. ${ }^{20}$ As anemia progresses, the unbalanced redistribution of blood flow causes congestive heart failure and increased interstitial fluid accumulation, resulting in skin edema and placental thickening. ${ }^{21}$ The imbalance between intravascular and extravascular fluid also decreases the blood supply to the fetal kidneys, which may later result in oligohydramnios. Therefore, we believe that the association between subcutaneous edema, placental thickening and oligohydramnios probably indicates a worst stage of fetal compromise, and may be used to determine the risk of adverse outcomes, even though no significant difference was found in our analysis, probably due to the small number of cases in our series.

Although this study is a retrospective analysis including a small number of cases, it is the first study to specifically examine the clinical and sonographic parameters associated with congenital parvovirus infection and to determine the association between these markers and different fetal outcomes. This knowledge will contribute to improve parental counselling. 
Nevertheless, we believe that an adequate sample size will not be achieved in a single center, as severe parvovirus fetal infections are rare, with the majority of the cases probably remaining unnoticed. Therefore, future published series should investigate more detailed parameters to enable a meta-analysis of individual patients with stronger evidence.

\section{Conclusion}

We identified no clinical or sonographic parameters that may be used to differentiate between the outcomes in fetuses with parvovirus congenital infection. We were not able to find those markers in our study; however, these data may provide some important guidance. The association between adverse outcomes and ultrasound parameters other than hydrops, such as subcutaneous edema, placental thickening and oligohydramnios, may indicate later stages of fetal compromise. However, further studies are necessary to conclude this association with consistency, mainly due to the small number of cases analyzed in the present study.

Conflicts to Interest

None to declare.

\section{References}

1 Cossart YE, Field AM, Cant B, Widdows D. Parvovirus-like particles in human sera. Lancet 1975;1(7898):72-73. Doi: 10.1016/S01406736(75)90509-7

2 Brown KE. Parvovirus infections. In: Longo DL, Fauci AS, Kasper DL, Hauser SL, Jameson J, Loscalzo J, eds. Harrison's principles of internal medicine. 18th ed. New York, NY: McGraw-Hill; 2012: 1478-1479

3 Rouger P, Gane P, Salmon C. Tissue distribution of $\mathrm{H}$, Lewis and P antigens as shown by a panel of 18 monoclonal antibodies. Rev $\mathrm{Fr}$ Transfus Immunohematol 1987;30(05):699-708. Doi: 10.1016/ S0338-4535(87)80138-1

4 Lamont RF, Sobel JD, Vaisbuch E, et al. Parvovirus B19 infection in human pregnancy. BJOG 2011;118(02):175-186. Doi: 10.1111/ j.1471-0528.2010.02749.x

5 Wright C, Hinchliffe SA, Taylor C. Fetal pathology in intrauterine death due to parvovirus B19 infection. Br J Obstet Gynaecol 1996; 103(02):133-136. Doi: 10.1111/j.1471-0528.1996.tb09664.x

6 Levy R, Weissman A, Blomberg G, Hagay ZJ. Infection by parvovirus B 19 during pregnancy: a review. Obstet Gynecol Surv 1997; 52(04):254-259
7 Yaegashi N, Niinuma T, Chisaka H, et al. The incidence of, and factors leading to, parvovirus B19-related hydrops fetalis following maternal infection; report of 10 cases and metaanalysis. J Infect 1998;37(01):28-35. Doi: 10.1016/S01634453(98)90346-2

8 Chorba T, Coccia P, Holman RC, et al. The role of parvovirus B19 in aplastic crisis and erythema infectiosum (fifth disease). J Infect Dis 1986;154(03):383-393. Doi: 10.1093/infdis/154.3.383

9 Schild RL, Bald R, Plath H, Eis-Hübinger AM, Enders G, Hansmann $M$. Intrauterine management of fetal parvovirus B19 infection. Ultrasound Obstet Gynecol 1999;13(03):161-166

10 Smoleniec JS, Pillai M. Management of fetal hydrops associated with parvovirus B19 infection. Br J Obstet Gynaecol 1994; 101(12):1079-1081. Doi: 10.1111/j.1471-0528.1994.tb13586.x

11 von Kaisenberg CS, Jonat W. Fetal parvovirus B19 infection. Ultrasound Obstet Gynecol 2001;18(03):280-288. Doi: 10.1046/j.14690705.2001.00471.x

12 Machin GA. Hydrops revisited: literature review of 1,414 cases published in the 1980s. Am J Med Genet 1989;34(03):366-390. Doi: 10.1002/ajmg.1320340313

13 Mari G, Deter RL, Carpenter RL, et al; Collaborative Group for Doppler Assessment of the Blood Velocity in Anemic Fetuses. Noninvasive diagnosis by Doppler ultrasonography of fetal anemia due to maternal red-cell alloimmunization. $\mathrm{N}$ Engl J Med 2000;342(01):9-14. Doi: 10.1056/NEJM200001063420102

14 Nicolaides KH, Soothill PW, Rodeck CH, Clewell W. Rh disease: intravascular fetal blood transfusion by cordocentesis. Fetal Ther 1986;1(04):185-192. Doi: 10.1159/000262267

15 Pedreira CE, Pinto FA, Pereira SP, Costa ES. Birth weight patterns by gestational age in Brazil. An Acad Bras Cienc 2011;83(02): 619-625. Doi: 10.1590/S0001-37652011005000008

16 Ismail KMK, Martin WL, Ghosh S, Whittle MJ, Kilby MD. Etiology and outcome of hydrops fetalis. J Matern Fetal Med 2001;10(03): 175-181. Doi: 10.1080/jmf.10.3.175.181-9

17 Kaiser L, Sükösd F, Veszprémi B, et al. [Parvovirus B19 infection in hydrops fetalis]. Orv Hetil 2000;141(30):1661-1665

18 Nicolaides KH, Soothill PW, Clewell WH, Rodeck CH, Mibashan RS, Campbell S. Fetal haemoglobin measurement in the assessment of red cell isoimmunisation. Lancet 1988;1(8594):1073-1075. Doi: 10.1016/S0140-6736(88)91896-X

19 Rodis JF, Borgida AF, Wilson M, et al. Management of parvovirus infection in pregnancy and outcomes of hydrops: a survey of members of the Society of Perinatal Obstetricians. Am J Obstet Gynecol 1998;179(04):985-988. Doi: 10.1016/S0002-9378(98) 70203-0

20 de Jong EP, Walther FJ, Kroes ACM, Oepkes D. Parvovirus B19 infection in pregnancy: new insights and management. Prenat Diagn 2011;31(05):419-425. Doi: 10.1002/pd.2714

21 Whitecar PW, Moise KJ Jr. Sonographic methods to detect fetal anemia in red blood cell alloimmunization. Obstet Gynecol Surv 2000;55(04):240-250 